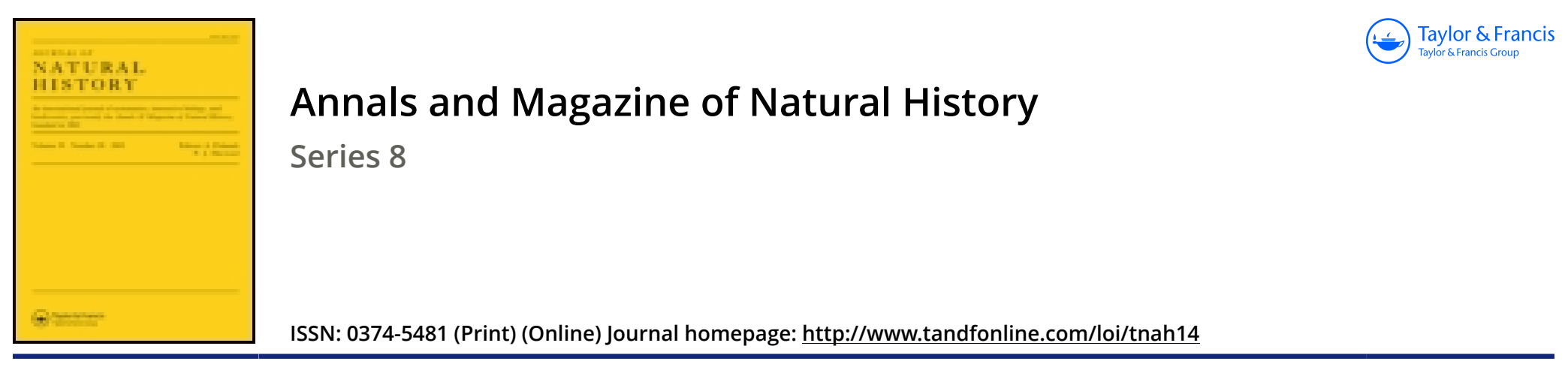

\title{
XLIX.-Descriptions of thirty new species of Tabani from Africa and Madagascar
}

\section{Gertrude Ricardo}

To cite this article: Gertrude Ricardo (1908) XLIX._-Descriptions of thirty new species of Tabani from Africa and Madagascar , Annals and Magazine of Natural History, 1:4, 311-333, DOI: 10.1080/00222930808692408

To link to this article: http://dx.doi.org/10.1080/00222930808692408

册 Published online: 08 Sep 2009.

Submit your article to this journal $\sqsubset \pi$

Џ Article views: 3

Q View related articles $\sqsubset$

4 Citing articles: 1 View citing articles 진 


\section{EXPLANATION OF THE PLATES.}

\section{Plate XII.}

Fig. 1. Leptocheirus subsalsus, sp. n. Antennules and antennæ.

Fig. 2,

Fig. 3.

Fig. 4 .

First gnathopod.

Fig. 5.

Fig. 6.

Second gnathopod.

Fig. 7. Leptocheirus bispinosus, sp. n. Secondary appendage of antennule.

Fig. 8.

Fig. 9.

$\begin{array}{cc}" & , \\ " & " \\ " & " \\ " & " \\ " & "\end{array}$

First peræopod.

Last peræopod, terminal joints.

Urosome.

Prate XIII.

Fig. 1. Leptocheirus bispinosus, sp. n. First gnathopod.

Fig. 2.

Fig. 3. " ". Urosome.

Second gnathopod.

Fig. 4. Leptocheirus pinguis, Stimpson. Secondary appendage of antennulo.

Fig. 5.

First gnathopod.

Fig. 6.

Fig. 7 .

Fig. 8 .

$\begin{array}{ll}" & " \\ " & " \\ " & "\end{array}$

Second gnathopod.

First perieopod.

Last peræopod, terminal jointo.

XLIX.-Descriptions of Thirty new Specis of Tabani from Africa and Madagascar. By Gertrude Ricardo.

[Concluded from p. 278.]

Tabanus tritceniatus, $\$$, sp. $n$.

One female (type) from Bailundo, Angola, Dec. 1904Jan. 1905 (Dr. F. C. Wellman), 1906. 139; one femalo from Bihé, Angola, Dec. 1904 (Dr. F. C. Wellman), 1906. 139.

A very small black species nearly allied to $T$. gratus, Loew, from which it is further distinguished by the shape of the middle callus, which is larger, occupying nearly the whole width of the forehead, and almost square, with its anterior and posterior borders of ten irregular, blackish brown; in T. gratus it is much smaller and narrower oblong in shape. Its small size will distinguish it at first sight, the type measuring $8 \mathrm{~mm}$., the other female only $6 \frac{1}{2} \mathrm{~mm}$.

Abdomen with three grey stripes, the middle one attaining the sixth segment, the side ones the fourth segment, but sometimes ending before this. Antennæ reddish; the first joint greyish with black-haired upper angle, the third blackish 
or brown at tip. Eyes with two stripes at least. Thorax with grey stripes. Frontal callus brown, shining, slightly protuberant, occupying whole width of head and connected by a short line with middle callus. Forehead grey, with black pubescence towards vertex. Legs reddisl. Wings quite clear.

\section{Tabanus unitoniatus, $\uparrow$, sp. $n$.}

Type (female) and another female from Pungwe Valley, S.E. Africa, 1896 (G.A.K. Marshall), 96. 84, at the fortieth mile-peg from commencement of Beira Railway; one female from Wau, Bahr-el-Ghazal, Egyptian Soudan, 25. vii. 1905 (per Dr. A. Balfour), " at light."

A species probably nearly related to $T$. unilineatus, Loew, from Mozambique, but distinguished from it by the redder abdomen, lighter fore tibix, the more slender palpi, the triangular frontal callus, and the larger size $(13 \mathrm{~mm}$.). It is a narrow-bodied reddish species, with a median white stripe on the abdomen and wings almost clear.

Head small, broader than the thorax. Face reddish, covered with grey tomentum and with short scanty white pubescence; beard white. Palpi yellow, thickly covered with black hairs, long and narrow, only slightly broader at the base, ending in an obtuse point. Antennæ bright red, the extreme apex black; the first joint short, broad, with a few black hairs; the second small, cap-shaped, with black hairs on its upper angle; the third with an obtuse tooth. Forehead about fonr times as long as it is broad and the same width throughout, reddish with some little grey tomentum; the callus shining red-brown, convex, oval, becoming narrower at its lower end, whence proceeds a narrow short raised line, which widens to a spindle-shaped callus; from the vertex a narrow black line proceeds in two branches surrounding this last. Eyes with no markings. 'Thorax reddish brown, with traces of grey tomentum and of three stripes, the sides reddish with grey tomentum. Abdomen narrow, reddish brown, with a greyish-white median stripe reaching the fifth segment, the apex black, the segmentations very narrowly white, the pubescence on dorsum mostly black ; underside testaceous with a black apex, in the other female it is very largely black. Legs reddish, the femora (especially the fore femora) blackish, the fore tibiæ blackest at their apex, and fore tarsi black. Wings hyaline, the stigma yellowish, the veins yellowish brown (in the other female the fore border has a very slight tinge of yellow); the first posterior cell not narrowed. 
Tabanus conspicuus, $q$, sp. $\mathrm{n}$.

Type and two other females from Yoiuti, Juba River, about 20 miles from mouth, E. African Protectorate, Feb. 1905 (Major L. H. R. Pope Hennessey). "Flew into cabin of steam launch."

A handsome medium-sized species, easily distinguished by its large size, yellow legs and antennx, and by the light yellow abdomen with only one grey median stripe hardly bordered by any darker colour, and lastly by its striped thorax.

Length $19 \mathrm{~mm}$. One specimen measures only $16 \mathrm{~mm}$.

Head large, wider than the thorax. Face reddish, covered with dense white tomentum, so that it appears whitish, with long white hairs below the antennæ; beard white. Palpi large, white, with no black pubescence, stout at base, prolonged to a point. Antennæ reddish, at apex black; the first joint with grey tomentum and black pubescence, cap-shaped; the second smaller, cup-shaped, with black pubescence; the third long with a moderate tooth. Forehead fairly broad, about five times as long as it is broad, and the same width throughout, the same colour as the face, but posteriorly more yellow, or altogether yellower; the callus reddish brown, shining, large, oblong, not reaching the eyes, prolonged as a stripe which is not always united to it and is often divided into two lengths, the last half being shorter, not reaching the vertex. Eyes with no stripes or markings. Thorax brown, with greyish-yellow tomentum forming three stripes, the median one narrower; sides greyer; pubescence short, scanty, and yellow, with some longer yellow hairs at the sides, bordered by black hairs above; breast grey, with whitish pubescence; scutellum the same colour as thorax. Abdomen large, yellow, with a central stripe of white tomentum composed of triangular-shaped spots with long apices each united to the preceding one; spot on the first segment is not always discernible; on the second segment the triangular shape is nearly obsolete; the stripe has a faint reddish border on each side, which after the fourth segment becomes black; the pubescence on the dorsum is short and black, intermixed with yellow pubescence, which is thicker at the sides; the sides of the first two segments have some grey tomentum ; underside yellow, with very narrow white segmentations, becoming darker at the apex. Legs reddish yellow; tibiz yellower; the coxæ covered with grey tomentum; the fore tarsi and extreme apex of tibiæ black, the other tarsi brownish; the pubescence on the fore coxa and femora silvery white, on the others shorter and yellow; on the tibiæ it is the same, but 
on the tarsi blackish; the last four joints of the fore tarsi rather broad. Wings longer than the abdomen, hyaline; the veins brownish, all with yellow-brown shading; the stigma yellowish; the first posterior cell slightly narrowed.

\section{Tabanus subangustus, $\&$, sp. n.}

The following specimens are in the British Museum collection :-

Type (female) from Abutshi, River Niger, W. Africa (A. Braham), 1903. 146; three females from N. Nigeria, 7. vii. 1905, \&c., received from Dr. J. H. Ashworth, Edinburgh University (coll. by Dr. Dalziel); one female from Odut, $\mathrm{S}$. Nigeria (Dr. Dudgeon).

This species is related to $T$. nigrohirtus, Ric., but distinguished at once by the broader forehead and frontal callus, and by the longer narrower abdomen, and the grey stripe is wider, about $1 \mathrm{~mm}$. in width, and more distinct; the posterior cell narrowed in T. nigrohirtus is not so in this species; both are West African species.

Length $17 \mathrm{~mm}$.

There are specimens in the Paris Museum, from Senegambia.

A reddish-brown species, with one grey median stripe and wings tinged with brown.

Head hardly wider than the thorax. Face reddish, covered with grey tomentum, on the sides of the cheeks it is yellower, some white hairs are visible on these last; beard yellowish white. Palpi yellow, covered with black pubescence; only slightly enlarged at the base, gradually tapering to a point. Antennæ bright red, long and slender; the first joint oblong, short, the second small with its upper corner prolonged, both with black pubescence; the third very.long and slender, the tooth small near the base, the extreme apex black; the subcallus the same as face. The forehead brown, rather broad, short, about three times as long as broad and the same width throughout; the frontal callus brown and shining, large, nearly square, almost reaching the eyes, on the posterior border irregular, prolonged in a line which enlarges, becoming spindle-shaped, and nearly reaches the vertex, which is brown; the sides boidering the callus are covered with yellow tomentum. Eyes with no markings. Thorax reddish brown with grey tonientum, through which blackish stripes appear; the sides and breast reddish, covered with grey tomentum and yellow hairs; the pubescence on sides of thorax black; the scutellum brownish. Abdomen dull reddish brown, with one 
continuous distinct stripe of grey tomentum, the sides of which are straight; the pubescence on the dorsum black, except on the stripe which has white hairs and at the sides are yellow hairs; underside reddish, darker at the apex. Legs brown; the tibia yellowish red, darker on apex in the fore tibiæ; the fore tarsi and the apical joints of the other tarsi brown; the apex of the femora yellowish; the pubescence on the coxæ whitish, elsewhere black and short. Wings longer than the body, hyaline, tinged with yellowish brown; veins yellow; stigma yellowish brown; all posterior cells widely open.

Tabanus albostriatus, + , sp. n.

The following specimens are in the British Museum collection :-

Type and another female from the Transval (Ross), 97. 99.

A black species with a white median stripe on the abdomen and grey side-spots. Antennæ blackish; the palpi very slender, pale yellow. Legs yellow, with darker femora. Eyes very slightly pubescent. Wings with an appendix, tinged with brown.

Length $13 \mathrm{~mm}$.

Head broader than thorax. Face grey, with scanty white pubescence; some black hairs below the antennæ; beard white. Palpi pale transparent yellow, curved, very slender, ending in a long point, slightly stouter at base, with some short black hairs. Antennæ slender; tooth very obtuse, only an angle; the first joint yellowish, covered with grey tomentum and black hairs, not very cap-shaped; the second small, yellowish, with black pubescence; the third black, red at its extreme base only. Forehead short, about four times as long as it is broad and same width throughout, grey, with small brown triangular frontal callus, not reaching the eyes, continued in a narrow thick line almost to the vertex, which is covered with grey tomentum ; the pubescence on the forehead black. Eyes with no band, the pubescence very slight and easily overlooked, the back of the head with white pubescence. Thorax blackish brown, covered with fairly dense short greyish pubescence, through which three grey stripes appear; the sides grey, with longer black hairs; the breast-bone covered with black hairs; a tuft of white hairs below near root of wings. Scutellum same colour as thorax, with the same pubescence. Abdomen blackish brown; the median white stripe continuous, its average width less than 
$1 \mathrm{~mm}$., with almost straight borders, it widens slightly on the second segment at the base; on the sides of the second, third, and fourth segments ill-defined but distinet grey spots appear, not reaching the sides, but taking up the whole width of the segment as a rule; the pubescence on the dorsum is short, thick, black, with three stripes of whitish-grey pubescence, covering the median stripe and the side-spots; these can best be seen by viewing the abdomen from the front; the lateral margins of the abdomen yellow, transparent, with whitish-grey pubescence; the underside brownish, the segmentations and the sides yellowish, the pubescence black, with two side stripes of the whitish-grey pubescence. Coxæ black, covered with grey tomentum and black and white pubescence; the fore femora blackish, the middle and posterior ones dull reddish with grey tomentum and whitish pubescence; the tibir yellow, the fore tibiæ reddish at the apex, at the base yellow with white pubescence, therefore with the appearance of fore tibir pale at base; the middle tibiæ with white pubescence at the base and black at the apex; the posterior tibia with black pubescence; the fore and rniddle tarsi brownish, the posterior ones yellow, all with black pubescence. Wings hyaline, slightly tinged with brown on the longitudinal veins, on the fore border and round the apices of the basal cells, and on the anal vein; the appendix distinct, the veins brown, the stigma small and yellowish brown.

This species is distinguished from Tabanus albilinea, Wlk., by its slightly pubescent eyes, blacker, more pubescent, and narrower abdomen, smaller size, darker antennæ, blackish frontal callus and stripe (not reddish brown as in the Walker species), darker femora, and more slender palpi.

\section{Tabanus obscurestriatus, $\uparrow$, sp. n.}

Type (female) from Congo, Nov. 18, 1904; 1904. 267 in the British Museum collection.

A small reddish species with a black median stripe and clear wings with a short appendix.

Length $12 \mathrm{~mm}$.

Head not large, but wider than the thorax. Face covered with grey tomentum, the pubescence silvery white; palpi reddish, with some white pubescence, stout at base, gradually tapering to a point; beard white. Between the antennæ and across the face is an indistinct reddish-brown band; the antennæ are reddish, slender, the tooth very slight, the first and second joints with black pubescence. Forehead about 
five times as long as broad and the same width throughout, above the antennæ shining reddish yellow, convex, with a median furrow; the frontal callus the same colour, nearly square, reaching the eyes and continued as a broad stripe nearly reaching the vertex; the forehead covered with yellowish tomentum, darker on the vertex. Eyes with no bands. Thorax brownish, with two fulvous lateral stripes bordered by a black one, all indistinct; the dorsum with grey tomentum and short fulvous pubescence, the sides with yellowish tomentum and black hairs, the breast with white pubescence; the scutellum the same colour as the thorax. Abdomen reddish; the black stripe begins from the first segment and is continuous to the apex, its borders not very clearly defined; the pubescence on the dorsum is black; the fourth, fifth, and sixth segments are yellowish and have yellow hairs at the sides, the seventh is wholly black, all the segments on the lateral margins are black; the underside wholly reddish, with yellowish pubescence. Legs reddish yellow; the anterior femora brown, the tibiæ pale yellow, with white pubescence; on the anterior tibiæ the apex is brown, the fore tarsi brown, the pubescence on the femora black. Wings clear, pale yellow on their extreme outer border, the veins and stigma yellowish, the appendix short but stout.

\section{Tabanus nigrostriatus, + , sp. $\mathrm{n}$.}

Type (female) from Plateau of Zomba, Nyasaland ( $R$. Sharpe), 97. 46, and a series of females from the same place.

A species quite distinct from any other African described species, with a long, narrow, bright chestnut-brown abdomen, which has a distinct black median stripe. Wings hyaline, tinged with brown, usually with an appendix, but this seems a variable character in this species.

Length $17 \frac{1}{2} \mathrm{~mm}$.

Head broader than thorax. Face reddish, covered with greyish-white tomentum and some white hairs; on the cheeks the ground-colour is more apparent; beard whitish yellow. Palpi yellow, with some black pubescence, long, only slightly broader at base, ending in an obtuse point. Antenuz red, sometimes darker at the apex (in one specimen only the base of the third joint is red); tooth fairly prominent; the first joint oblong, the second small, both with black pubescence. Forehead brownish, about four times as long as broad and slightly narrower anteriorly; the subcallus reddish, with yellow-grey tomentum round the base of the antenna; the frontal callus dark brown, shining, convex, hardly reaching the eyes, 
prolonged in a narrow line, which enlarges spindle-shaped, almost reaching the vertex ; the tomentum bordering it is yellowish. Eyes bare, with no markings. Thorax reddish brown, with traces of black stripes, one broad and two lateral stripes, the red ground-colour appearing between as narrow lines, the dorsum with grey tomentum; the sides and breast reddish brown, with grey tomentum ; the scutellum blackish. Abdomen light reddish brown, the segmentations very faintly yellow; the black stripe composed of oblong black spots on each segment, beginning from the second, almost joining, and giving the appearance of a continuous narrow black stripe on which no grey tomentum or spots appear; on the first segment there is an indistinct median black spot, on the fifth and sixth segments the stripe is broader, and the seventh segment is almost entirely black ; the lateral margins of the fifth and sixth are yellow, transparent; the pubescence on the dorsum is black and short, thickest on the sides, sometimes there are traces of yellow pubescence on the segmentations; on the seventh segment the black hairs are long; underside same colour, with no black stripe visible, but the apex black. Legs blackish brown, the tibiæ the same colour as the abdomen, the fore tibiæ brown at the apex, the tarsi brown on their apical joints; the pubescence on the coxæ and femora whitish and the femora with whitish tomentum, some few yellow hairs on the fore tibiæ; otherwise the pubescence is black, short, not very noticeable. Wings hyaline, tinged with brown, darkest on the fore border; the appendix, when present, is short, thick, and indistinct (on two of the specimens it is entirely absent), the stigma brown, veins brown, all cells widely open.

\section{Tabanus kingsleyi, $q$, sp. $\mathrm{n}$.}

The following specimens are in the British Museum collection :-

Type (female) from Port Lokkoh, Sierra Leone, April 1904 (Major F. Smith), 1904. 143; and four other females, on one of which is attached the following note:- "Numerous, no other species about; bit donor severely in the house, several hundred yards from the water. Dry season, April." One female from near Baiwalla, Sierra Leone, June 1903 (Dr. H. J. Conyngham), 1903. 292.

A species belonging to the group of Tabanus treniola, Macq., with the typical light abdominal stripes bordered by darker ones, but bearing some resemblance to Tabanus gabonensis, Macq., and Fabanus secedens, Wlk.; distinguished from them, 
however, by the side stripes composed of spots contiguous to each other, and thus forming a distinct stripe, whereas in Tabanus secedens the side spots are isolated and the whole abdomen is of a reddish-brown shade, any gradations in colour merging in each other, not forming well-marked dark stripes as in the $T$. toeniola group. It is distinguished from $T$. taniola by the heavily striped thorax, similar to that of $T$. gabonensis \&c., and by the wings tinged with brown, shaded on most of the veins.

Length $13-16 \mathrm{~mm}$.

Face covered with greyish tomentum, which becomes yellowish brown above the antennæ, and with short white pubescence; beard whitish. Palpi pale yellow, with white pubescence at base and short black pubescence elsewhere, not very strut at base, ending in a broad point. Antennæ reddish; the first joint rather smaller than is usual, with black pubescence; the second small, with black pubescence; the third long, with small tooth near the base, becoming brownish red after the base; and the last four divisions wholly blackish. Forehead covered with yellowish-brown tomentum, nearly six times as long as it is broad, narrowing slightly anteriorly; the frontal callus dark brown, oblong, furrowed in the middle, almost or entirely reaching the eyes, with a long thick line proceeding from it. Thorax blackish, the two broad stripes composed of grey tomentum, covered with yellow pubescence; sides greyish, with some yellow pubescence, which is continued round base of thorax, elsewhere it is black ; breast and sides covered with grey tomentum and some white pubescence. Scutellum blackish, covered with greyish tomentum except in the centre. Abdomen reddish brown, blackish on the last three segments, with a distinct grey, tomentose, median, continuous stripe, continued to the sixth segment, bordered by dark brown or blackish stripes, to which are contiguous the yellowish side spots, forming a fairly distinct stripe as far as the fourth segment; the pubescence on median stripe and on the side spots is chiefly yellowish, elsewhere black; underside yellowish, with broad black median stripe, covered with white pubescence. Legs blackish; tibiæ yellowish, black at apex ; middle and posterior femora often largely yellowish red, femora with grey tomentum and white pubescence; the tibiæ with whitish pubescence, elsewhere it is black. Wings hyaline, tinged with brown, most intense on the fore border ; stigma reddish brown, veins brown. 
Tabanus quadrisignatus, + , sp. $\mathrm{n}$.

The following specimens are in the British Museum collection :-

Type (female) and another female from Ruwe, Lualaba River, Congo Free State, circa $11^{\circ}$ S., 26 ${ }^{\circ}$ E., Feb. 1906 (Dr. A. Yale Massey), 1906. 98.

A well-marked species nearly related to Tabanus fraternus, Macq., better known as Tabanus trisignatus, Loew (which is a synonym of the Macquart species), but easily distinguished from it by the four distinct triangular median spots, the older species having only three, and by the heavily striped thorax and bright red-yellow antennæ. In the thoracic stripes it resembles Tabanus kingsleyi, from which it is distinguished by the markings of the abdomen.

It is a medium-sized species with black thorax, marked with two distinct broad greyish stripes, a reddish-brown abdomen with yellowish-grey side spots besides the median ones, blackish legs with red-yellow tibiæ, and clear wings very slightly tinged brown.

Length $13 \frac{1}{2}-15 \mathrm{~mm}$.

Head wider than thorax. Face reddish (denuded), in the other specimen it is covered with greyish-yellow tomentum and with white pubescence; beard white. Palpi very pale yellow, with white pubescence, slightly broader at base, ending in a moderate point. Antennæ bright red-yellow; the first joint cylindrical, hardly at all cap-shaped, with greyish tomentum and black pubescence and a few white hairs; the second very small, with black pubescence; the third long, darker at its apex, with a moderate tooth. Forehead reddish (denuded), with yellowish-grey tomentum, nearly five times as long as it is broad, narrowing anteriorly; the frontal callus red-brown, oblong, not reaching the eyes, the line proceeding from it is short and thick, some black hairs on the vertex. Thorax blackish brown, the two broad stripes continued to base, composed of grey tomentum, with yellowish pubescence; sides with grey tomentum, the pubescence on dorsum black, with whitish hairs round the base of wings and continued from the base of the stripes round thorax to the sides. Breast and sides reddish, covered with grey tomentum and with white pubescence; black hairs above. Scutellum reddish yellow at base, black in the centre, with black pubescence and yellowish hairs elsewhere. Abdomen reddish brown; some grey tomentum on the first segment, on the four following segments a grey, tomentose, median, triangular spot, all with broad bases, the first one 
longest, all with whitish pubescence; the side spots in the type are large on the second segment, smaller on the third and fourth segments, all yellowish in colour, with grey tomentum and some white hairs, irregular in shape; the fith segment is black at the sides and the sixth wholly black, both, however, with yellow transparent side margins; in the other female there traces of side spots on the fifth segment; pubescence on dorsum black, yellowish on the lighter spots, sides with white pubescence, black at the extreme apex; underside pale reddish yellow, blackish at the apex, with chiefly white pubescence. Halteres brown, with whitish knob. Legs blackish brown, with red-yellow tibir; they are similar to those of Tubanus coniformis, Ricardo. Wings clear, very slightly tinged round veins with pale yellowish brown; the first posterior cell slightly narrowed at opening; veins brown, stigma yellowish.

\section{Tabanus coniformis, + , sp. $\mathrm{n}$.}

The following specimens are in the British Museum collection :-

Type (female) and another from Ruwe, Lualaba River, Congo Free State, circa $11^{\circ}$ S., $26^{\circ}$ E., Feb. 1906 (Dr. A. Yale Massey), 1906. 98; two females from Benguella, Angola, 1905 (Dr. F. C. Wellman), 1906.139. "Entangled in an old spider's web near my bungalow."

A species not belonging to any very distinct group, but nearest to that one represented by Tabanus toniola, Macq. It is a slender reddish-brown species, with the abdomen very pointed at the apex, with indistinct median and side spots and a black apex; the legs are blackish, with red-yellow tibix; the wings quite clear, with no appendix. Antennæ red-yellow.

Length $14 \mathrm{~mm}$.

Head wider than thorax. Face covered with greyish tomentum, which becomes yellowish brown on the subcallus and extreme borders of cheeks, pubescence white; beard white. Palpi yellowish red, with thick short white pubescence, moderately stout, with short apex. Antemna reddish; the first joint cap-shaped, with white pubescence and black hairs on the upper angle; second small, with whitish pubescence; the third long, with moderate tooth; the last four divisions nearly as long as the first division; the extreme apex black. Forehead red, covered with same coloured tomentum as the subcallus; the frontal callus reddish brown, hardly reaching the eyes, oval, with a thick line proceeding from it Ann. E Mag. N. Hist. Ser. 8. Vol. i. 
which is furrowed in the middle and nearly reaches the vertex ; the forehead is about four times as long as it is broad, only slightly narrower anteriorly. Eyes with no markings. Thorax reddish brown, with darker indistinct stripes and with indistinct grey stripes; the dorsum with greyish tomentum and some black pubescence, traces of whitish pubescence round the roots of wings and base of thorax; sides and breast covered with greyish tomentum and white hairs. Scutellum reddish, black at base, with grey tomentum and a few white and black hairs. Abdomen reddish brown, with triangular, narrow, grey, median, tomentose spots, only distinct when viewed from hehind and only on the second, third, and fourth segments; the sides with irregular, reddish-yellow, oblong spots covered with greyish tomentum on ihe first four segments; the last three segments are wholly back, the fifth and sixth with lighter segmentations; the pubescence on the dorsum black; on the posterior borders of the fifth and sixth segments with white and black hairs, the sides with white pubescence, black at the apex; underside reddish yellow, black at apex, the segmentations very narrowly white; pubescence white, black at apex. Legs blackish brown, the fore tibiæ red-yellow on basal half, the other tibiæe wholly red-yellow; the middle and posterior tarsi the same colour, but blacker at apex; the pubescence on coxæ and femora is white, with some grey tomentum; on the fore tibiæ white on basal half, elsewhere black, with some white pubescence on the middle and posterior tibia. Halteres with dark stem and a yellowish knob.

\section{Tabanus brunnescens, $q$, sp. $\mathrm{n}$.}

The following specimens are in the British Museum collection :-

'Iype (female) and another female from the Gold Coast, Sept. 1905 (lir. McConell); two females from Obuasi, S. Ashanti, 6. iii. 06 (J)r. W. M. Graham), 1906. 150. "Cauglit in house on window."

A smaller darker species than $T$.gabonensis and $T$. secedens, with a short abdomen, distinguished from them by the thoracic stripes, which are broad and two in number, wholly covered with yellow pubescence, the same width throughout, not showing the suture of thorax as is usual in the above species, and continued to the scutellum, leaving only the middle of it black, with black pubescence. The abdomen is darker in colous, not marked with darker segmentations, but more uniformly dark brown; the median stripe continuous, yellowish ied, covered with yellow and black pubescence, and the side 
spots indistinct yellowish. The legs are rather darker than those of T. gabonensis.

Length $16 \mathrm{~mm}$.

One of the specimens from Ashanti has the pubescence on the thoracic stripes and median abdominal stripe more grey than yellow.

Head large, wider than the thorax. Face covered with whitish tomentum, which is yellowish brown above the antennæ, the pubescence white, short, scantv; beard white. Palpi yellowish, the same shape as those of Tabanus claripes, sp. n., with black pubescence. The antenne are also similar in shape, red, with black pubescence; the third joint is wanting. Forehead yellowish brown; callus dark brown, long, almost reaching the eyes, with a thick line proceeding. from it ; forehead on posterior half and at sides dark brown, with black pubescence, the yellowish-brown colour only appearing around the line proceeding from callus and at the sides; the hind margin of head narrow, yellowish. Thorax dark brown, with two broad median and two narrower side stripes composed of greyish-yellow tomentum with yellow pubescence, the pubescence on the dark part of the thorax black. Scutellum brown, the yellow thoracic stripes reaching its apex and continued round it. Abdomen rather short, stout, dark reddish brown, the median continuous stripe fulvous, reaching from the second to the fifth segment; on the sides of the second and third segments appear reddishyellow indistinct spots; the pubescence of dorsum is yellowish on the stripe, otherwise black, short, and thick; underside pale yellowish, with a dark brown broad median stripe; the pubescence short, white on the pale colour and black on the dark stripe. Legs blackish ; fore tibia at base pale yellowish red; the middle and posterior tibia dull red on the basal half; the pubescence on the coxæ white, on the femora black, on the fore tibix whitish on the pale colour, black at the apex, on the other tibiæ it is black with some fulvous hairs; tarsi with black pubescence. Wings tinged pale brownish, lighter in centre of cells; no appendix.

\section{Tabanus claripes, $q$, sp. $n$.}

The following specimens are in the British Museum collection:-

The type (female) from Leopoldville, Congo, Jan. 18, 1904 (coll. Drs. Dutton, Todd, and Christy), presented by the Liverpool School of Tropical Medicine, 1904. 267, is in the British Museum collection. 
A large reddish-brown species with striped thorax and brownish wings, easily distinguished by its bright reddishyellow coxæ from Tabanus secedens, Wlk., and Tabanus gabonensis, Macq., and by its larger size and redder legs, the fore femora being red, not blackish, and by the markings of the abdomen, which consist of distinct, grey, median, triangular spots, not continuous, and of indistinct reddish-yellow side spots.

Length $24 \mathrm{~mm}$.

Head large, wider than thorax. Face covered with greyish tomentum, yellowish at sides of cheoks and above antennæ on subcallus, pubescence whitish, short, longer on lower part of face; beard whitish. Antennæ dark reddish brown, blackish at apex ; the first joint large, cap-shaped, with black pubescence, thickest on the upper angle; the second small, with black pubescence; the third large, with small, rather acute tooth, with brownish tomentum on the first division. Forehead long, narrow, about seven times as long as broad, narrowed anteriorly, yellow like the subcallus; frontal callus bright reddish brown, long, almost reaching the eyes, furrowed in the middle and continued as a thick line beyond the middle of the forehead; the pubescence of the forehead consists of a few black short hairs and of yellowish hairs beyond. Palpi long, curved, not very stout at base, ending in a long point, yellow, covered with short black pubescence. Thorax brown, with two broad median stripes and two narrower side stripes composed of pale yellowish tomentum ; pubescence on dorsum short, black, on the stripes yellowish, with tufts of longer white hairs at base of wings ; sides and breast covered with greyish tomentum and white hairs. Scutellum brown, with yellowish tomentum, redder at apex; the pubescence black, short. Abdomen long, stout, brown, with reddish colour appearing on the first aud second segments and at sides; on the first segment there is a trace of a grey spot, on the second segment it is almost oblong, barely wider at the base; on the third segment it is a long triangular spot reaching the fore border; on the fourth segment it is a brcader triangular spot not reaching the fore border; on the sixth segment it is a very short triangular spot; all these spots are greyish yellow, covered with greyish-yellow hairs; the reddish colour of abdomen appears as indistinct irregularshaped markings on the sides; the pubescence of the dorsum is short, black, rather thick, on the sides it is white; the side-borders of the last segments are yellow, transparent; the underside pale reddish, with a darker median broad stripe covered with short white pubescence: Legs bright red; the 
coxæ at their extreme apex and the middle coxæ wholly black; the knees, apex of fore tibia, and the fore tarsi blackish; the fore tibiæ are pale yellowish on their upper surface; the pubescence on the fore coxæ is long, white, on the other coxæ scanty and short; on the femora it is white, longest and thickest on the fore pair, with some black pubescence; on the fore tibiæ it is white on the pale colnur, black at the apex, and blark on the other tibix; the tarsi with thick black pubescence. Wings pale brownish, yellowish brown on the fore border, with sone clear spaces in the millde of the cells; veins and stigma brown; the first posterior cell a little narrowed at its opening; no appendix.

\section{Tubanus disjunctus, $\uparrow, \mathrm{sp} . \mathrm{n}$.}

The following specimens are in the British Museum collection :-

Type (female) and another from Lutete, Congo, Nov. 19, 1903, presented by the Liverpool School of 'Tropical Medicine, 1904. 267.

A species with three series of grey spots on the abdomen similar to those of Tabanus distinctus, Ricardo, to which it is closely related, but the median spots in this species are not connected and the legs are more wholly reddish, the fore femora not being brownish; it is also larger in size and browner in colour. It is distinguished from Tubanus perrasus, Wlk. (probably the same as the South-African form of I'abanus bovinuss), by the clear wings and the more distinct triangular side spots with their bases resting on the posterior borders of the segments. It is distinguished from Tabanus stic/icalis, Surcouf, from Font el Julon, N. of Sierra Leone, by its larger size and more distinctly defined side spots.

Length $20 \mathrm{~mm}$.

It differs from Tubanus distinctus in the following particulars :- Face covered with yellowish-brown totnentum and with short thick white hairs. Palpi light yellow, larger and rather stonter. Antennæ rather darker; the third $\mathrm{j}$ rint blackish only, red at the base. Forehead covered with yellowish tomentum; vertex not reddish, but with the same tomentum; the few hairs on the forehead seem chiefly yellowish; it is about six times as long as it is broad, narrowing slightly anteriorly. 'I'horax brownish, with five indistinct grey stripes, and the scutellum the same colour. Abdomen brown; the median spot on the second segment with long apex, which, however, does not reach the posterior border of the first segment; the second spot on the third 
segment triangular, with a very short apex barely reaching half the width of the segment; the third spot with a slightly longer apex; the fourth spot on the fifth segment subtriangular, nearly reaching the posterior border of the next segment; on the sixth and seventh segments there are no spots; the side spots are four in number on each side, almost similar in shape to those of Tabanus distinctus, but not so well detined, more irregular in shape; underside reddish, with white-haired segmentations. Legs reddish, the extreme apex of the fore coxæ and extreme apex of fore femora, the apices of the fure tibiæ, and the tarsi blackish; the coxæ with long white pubescence; the fore femora with short black pubescence above and long white below ; on the outer border of the other femora it is also white but not so long; the fore tibiæ with thick white pubescence on their basal half, giving them a whitish appearance; the other tibia with chiefly white rubescence, on the tarsi it is black. Wings clear, yellowish on fore burder; stigma yellowish; veins brown; the first posterior cell slightly narrowed at opening.

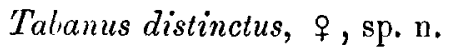

The following specimens are in the British Museum collection :-

Type (female) from Benguella, Angola (A. T. Massey, per Col. Giles), and another female from Lake Tanganyilia (W. A. Cunnington), 1906. 76.

A medium-sized species with light reddish-brown abdomen very distinctly marked with three series of grey triangular spots and thorax with fairly distinct grey stripes. It is distinguished from Tabanus congoiensis, sp. n., by the quite clear wings and shape of side spots of abdomen, which are isosceles triangles with their bases resting on the posterior borders of segments.

Length $15 \frac{1}{2} \mathrm{~mm}$.

Head wider than the thorax. Face reddish yellow, covered with greyish-white tomentum and with short thick white pubescence on the cheeks and lower part of face; beard white, long. Palpi pale yellow, with yellowish-white pubescence and tiaces of a few black hairs, stout at base, slightly curved, ending in a long point. Antennæ red; the first joint very slightly cap-shaped, with black hairs on the upper angle and some white hairs on its outer border; the second very small, with black pubescence; the third dull red, with obtuse tooth, black at the extreme apex. Forelead covered with grey tomentum; the frontal callus reddish 
brown, shining, barely reaching the eyes, long, with a short stout line proceeding from it ; the vertex (? denuded) reddish brown, a few black hairs on the sides; the forehead narrows anteriorly a little and is about five times as long as it is broad; back of head whitish, with white hairs. Thorax reddish, with five grey indistinct and four black stripes; the grey stripes are comjosed of grey tomentum, the median one is narrow, with a broader one on each side and side-stripes; the two middle black stripes only reach the suture; these black stripes only appear as stripes contrasted with the reddish ground-colour of the thorax, which is not apparent in the specimen from Lake Tanganyika, the thorax being blackish, with the five grey stripes apparent, which may probably prove a more correct description of this species when a long series is available for comparison; pubescence on dorsum black, on the grey stripes whitish yellow, sirles with black hairs, and with white hairs near the root of wings; breast and sides reddish, with grey tomentum and white hairs. Scutellum reddich, with black pubescence and yellowish hairs round the margin. Ablonen reddish, darker at apex, with three distinct, grey, tomentose triangular spots on the second, third, fourth, and fifth segments; there are traces of them on the sixth; the seventh is wholly black; the median spots are roughly equilateral triangles with broad bases resting on the posterior border of each segment and each apex reaching the base of the succeeding spot, all almust equal in size, except the one cn the sixth segment, which is smaller; the side spots are isosceles right-angled triangles with the side nearest the median spots and the base, which jests on the posterior border of segment, straight, both together forming a right angle; the pubescence of dorsum black, on the grey spots yellowish or white; sides of abdomen with white hairs, at the aper some black hairs; underside pale yellowish red, with grey tomentum and pubeseence. Legs yellowish red, the apices of fore coxa and the fore femora reddish brown, the fore tarsi and the apices ot fore tibia blackish, the other tarsi brownish; the coxie with long. white pubescence, the fore and middle femora with black pubescence above and some white below; the pusterior femora with wholly white pubescence, the fore tibia with whitish hairs on the yellowish base, the other tibia with chietly whitish pubescence, elsewhere it is black. Wings clear; vein:s bronn ; stigma yellowish brown, the first posterior cell distinctly narrower at opening; no appendix.

The specimen from Lake langanyika is browner in colour. 
Tabanus congoiensis, + , sp. n.

The following specimens are in the British Museum collection :-

Type (female) and tro other females from Wathen, Congo Free State (Rev. W. H. Bentley), 1904. 207, and one female from Tumbo, Congo, Nov. 5, 1903 (presented by the Liverpool Scliool of Tropical Medicine).

A dark brown species with well-marked grey triangular median spots and side spots; greyish stripes on the brown thorax, reddish legs, and wings greyish, tinged yellowish brown round the veins and on the fore border.

Length $16 \mathrm{~mm}$.

The specimen from Tumbo measures $18 \frac{1}{2} \mathrm{~mm}$. It is distinguished from Tabanus temperatus, Wlk. (which is probably the same as the South African variety of Tabanus bovinus), by its smaller size and narrower abdomen, the median triangular spot on the second segment is narrower at its base and more oblong in shape, the colour of the abdomen is more largely a uniform dark brown with the side spots small, but fairly distinct.

Head wider than thorax. Face reddish, densely covered with greyish tomentum, the ground-colour perceptible on the upper part of face and on the subcallus, where the tomentum is also more yellow in colour; the pubescence white, consisting of rather longer white hairs in middle of face below the antennæ and of shorter ones on the cheeks ; beard white, scanty. Palpi yellow with thick black pubescence, long, wide at the base, tapering to an obtuse point. Anternnæ dull reddish, black at apex; the first joint large with black pubescence; the second small, with black hairs on the upper prolongation and outer border; the third long, wide at the base, with an obtuse tooth. Forehead about six times as long as it is broad, narrower anteriorly, red with brown and yellow tonientum ; the frontal callus reddish brown, oblong, convex, almost reaching the eyes, continued in a thick line halfway along the forehead. Eyes with no markings. Thorax brownish with two stripes of grey tomentum continued to the base of the thorax, grey at sides and on the anterior border, the pubescence of black rather long hairs, with traces of some yellow pubescence; the sides of thorax more red, with black pubescence; breast red, with grey tomentum and black jubescence and some white hairs ; the scutellum reddish, with black and yellowish pubescence and traces of grey tomentum. Abdomen brownish, appearing reddish brown on the second segment; the first segment covered with grey tomentum on 
the anterior border, on the posterior border a small, median, yellowish spot with yellow hair divided in half by a line or furrow ; on the second segment the grey triangular spot is long, reaching the anterior border, narrow at its base; on the three following segments the spots are wider and shorter, not reaching the anterior border; on the sides of the second, third, and fourth segments an isolated, roundish, grey spot is visible; in one of the other females from Wathen the spots are more distinct and oblong, and a small one is perceptible on the fifth segment, the segmentations from the third segment are narrowly whitish; the dorsum rather thickly covered with short black hairs, a few yellow hairs are visible on the bases of the grey triangles ; underside reddish, transparent, with white segmentations and pubescence; the margins of abdomen on the fourth, fifth, and sixth segments are yellow, transparent, with some white pubescence. In one of the specimens the side spots are rather indistinct, the triangle on the second segment does not reach the fore border, and the abdomen is darker, showing no light segmentations. Legs reddish, the fore $\operatorname{cox} 2$ blackish with long white hairs; the pubescence on the femora black, on the fore tibia white, on the middle and posterior tibire black; the apex of the fore tibiæ and all tarsi blackish; some grey tomentum on the femora. Wings greyish, tinged with yellowish brown on all the reins and on fore border; stigma the same colour; veins brown. In a third specimen from the same place the side spots are rather indistinct, the triangle on the second segment does not reach fore border, and the abdomen is larger, showing no light segmentations.

Tabanus silvanus, , $\mathrm{sp} . \mathrm{n}$.

The following specimens are in the British Museum collection :-

Type (female) and another from Amboilimitombo Forest, Madagascar (Forsyth Major Coll.), 98. 46.

A dark brown species with almost clear wings ; the abdomen obscurely brown, with distinct, grey, median, triangular spots and narrow grey segmentations; the antennæ blackish. Legs dull reddish.

Length $15 \mathrm{~mm}$.

This species is probably related to Tabanus atrimanus, Loew, but distinguished from it by the absence of the large, tomentose, white side spots on the second segment, and by the legs being radder.

Head broader than thorax. Face greyish white with white 
hairs; beard white. Palpi yellow ; fuirly stout at base, tapering to a point; some black hairs visible. Forehead the same colour as the face; the subcallus with wrinkles and a fine median black line. Frontal callus reddish brown, oblong, not reaching the eyes, prolonged as a fine line; on the vertex a short reddish stripe, grey in the centre, is apparent; tomentum on posterior half of the forehead yellowish. Antenne blackish ; the first and second joints and base of the third dark reddish brown. Thorax brown, shining, with four grey stripes and a median lineal yellowish stripe; the sides greyish with grey hairs, with black hairs above, reaching to the wings. Scutellum brown with some grey tomentum. Abdomen dark reddish brown, short, with grey tomentum; on the first segment is an imperfect triangular grey spot in the centre; on the second a median triangular grey spot hardly reaching beyond half the width of the segment; on the third segment a similar spot with shorter apex; the three following segments with similar spots which become smaller and more oblong in shape; all the segmentations after the third segment are whitish, becoming broader at the sides; the brown colour becomes darker round the grey triangular spots; the dorsum is devoid of pubescence; the sides are bordered with tine short white hairs; the underside brownish, with white segmentations and short white pubescence. Legs reddish brown; the fore legs darker with the exception of the base of the tibir, the pubescence greyish, short. Wings hyaline; the veins and stigma dark brown, the cross-veins at the apices of the basal cells have a slight shading which is hardly perceptible in the upper cross-veins; no posterior cells narrowed at their apices.

\section{Tabanus diversus, o, sp. n.}

The following specimens are in the British Museum collection :-

Type (female) and another from Rure, Lualaba River, Congo Free State, circa $11^{\circ}$ S., $26^{\circ}$ E., Feb. 1906 (Dr. A. Yale Massey), 1906. 98.

This small black species, with the abdomen marked with very distinct grey spots and thorax with grey stripes and spots, clear wings, short antennx, and brown legs with yellowish tibix, is very nearly allied to Tabanus insignis, Loew, from E. Alrica, but easily distinguished by its black, not brown colour, by the absence of the four white spots on the second segment of abdomen, by the different, more oblong shape of the large spots on the third and fourth seg- 
ments, by the shorter antennæ, the frontal callus with a very short, thick line proceeding from it, and the thorax with two greyish-laired spots at the base and no white tomentose margin as in T. insignis.

Length $11 \frac{1}{4} \mathrm{~mm}$.

Head wider than thorax. Face covered with grey tomentum and with white pubescence; beard white. Palpi yellow, with fairly long, white pubescence, moderately stout at base, ending in a long acute point. Antennæ short, reddish; the first joint yellowish, with black pubescence on the upper angle and whitish elsewhere, cylindrical, hardly at all capshaped; the second small, red, with black pubescence; the third red, at apex black, with broad, short, first division, and tooth marked by an angle; the last four joints very small. Forehead fairly broad, very slightly narrower anteriorly, about four times as long as it is broad, brown, covered with grey tomentum and with some grey and black hairs; the frontal callus reddish brown, nearly square, alinost reaching the eyes, the line proceeding from it is very short and thick; in the second specimen it is broader still, nearly as broad as the callus itself, on each side of this line the brown groundcolour appears as an ill-defined long spot; the vertex is brownish. Back of head whitish with white hairs. Thorax black, shining, with two median, grey, tomentose stripes, not reaching beyond the middle of thorax, at base of thorax two grey hairy spots ; sides grey with white pubescence; on the stripes the pubescence is whitish, elsewhere black; at the base of thorax near the root of the wings there is thick white pubescence. Sides and breast with grey tomentum and white pubescence. Scutellum dull reddish, with grey tomentum and white pubescence. Abdomen black; on first segment trace of a small, grey, median spot and at sides broadly white, tomentose; second segment with white tomentose spot on each side, its upper angle pointing inwards and reaching three quarters of the width of the segment, and continued up the whole outer side of segment; the side spots on the four following segments are very similar, decreasing in size, the upper angles especially so; on the third segment the large white median spot is almost square, extending the whole width of segment; on the fourth it is rather smaller; all these spots are covered with grey tomentum and white pubescence, the pubescence on the dorsum is otherwise black, on the sides white; underside dull reddish yellow, blackish at sides and towards the apex, covered with short white pubescence. Legs blackish brown; the tibire yellowish, the fore tibir klack on apical half; the femora with greyish 
tomentum and white pubescence; the tibia with yellowishwhite pubescence, black on dark apex of fore tibia and elsewhere. Wings clear, veins brown, stigma yellowish brown; the first posterior cell not narrowed; no appendix.

Tabanus fuscipes, ơ ㅇ, sp. n.

The following specimens are in the British Museum collection :-

Type (female) from British Central Africa, 1906 (E. L. Rhoades); one female from Gadzima, Mashonaland, Dec. 1895 (G. A. K. Marshall), 1903. 17; one female from Salisbury, Mashonaland, Dec. 1899 (G. A.K. Marshall) ; one male from Estcourt, Natal, Jan. 1897 (G. A. K. Marshall), 1903. 17.

This species is very nearly related to Tabanus ditceniatus, Macq., and may be easily confused with it at first sight, but is a distinct species, recognized by the black coxx and almost wholly blackish femora and by the absence of any grey tomentum in the centre of the median black stripe of abdomen.

Juength 12-14 $\mathrm{mm}$.

The antennæ are slightly darker at the apex. The eyes, face, palpi, and forehead similar to those of $T$. ditoniatus, with the two typical black spots on the forehead. There is no trace of grey triangles on the black stripe of abdomen in the females. The yellow legs are darker, the femora all being black for two thirds of their length, the apical third alone being yellow. The clear wings have a short appendix.

The male has yellowish eyes, brown below, the facettes all equal, except those on the lower third of eye which are smaller, no stripe apparent. Palpi club-shaped, yellow, transparent. 'The abdomen has the apex more widely black than in the females and a grey tomentose stripe is visible on the median black stripe; the legs are similar to those of the females, but the femora are almost wholly black, only their extreme apex being yellow.

\section{Tabanus ruwenzorii, + , sp. $\mathrm{n}$.}

One female (type) from E. Ruwenzori, 5000-7000 feet, 22. i. 1906 (coll. by Hon. G. Legge and A. F. R. Woollaston), 1906. 153; another female from E. Ruwenzori, 6001300 feet, 7. ii. 1906 (by same collectors).

A robust pubescent species with hairy eyes, black abdomen with the second segment reddish at the side, thorax shining black. Antenuæ, face, and palpi black. Legs 
black, tibiæ yellow. Wings clear, very slightly tinged yellowish brown.

liength $16 \mathrm{~mm}$.

Face black, with dull brown tomentum and yellowish-brown pubescence, some black hairs on the upper part of cheeks and under antennæ; beard yellowish brown. Palpi dull brownish black with black pubescence, stout, ending in a short point. Antennæ black, with long and slender third joint and hardly any tooth; the first two joints with long black pubescence; the subcallus the same colour as the face. Forehead about three times as long as broad, the same width throughout, dull blackish brown with yellowish-brown tomentum and long black pubescence; the frontal callus small, reddish brown, oval, the line proceeding from it indistinct; the vertex black, with tubercle. Eyes covered with short yellowishbrown pubescence. Thorax black, shining, with no stripes; the dorsum nearly bare; shoulder-spots reddish with some yellowish-grey hairs, which are continued round the base of the thorax; sides with black pubescence; breast black, with greyish-yellow pubescence and some black hairs. Scutellum shining, black. Ablomen black, somewhat shining; the first segment narrowly red at the sides; the second segment broadly red at the sides with narrow reddish segmentations; the following segments with extremely narrow, grey-haired segmentations. Legs black; tibiæ yellowish with apices black; the femora with greyish pubescence; the tibiæ with dense whitish pubescence, on their black apices and on the tarsi it is black. Wings hyaline, the yellowish-brown colouring is chicfly round the longitudinal veins of the fore border and is very faint; veins and stigma brown.

\section{L.-Description of a new Elapine Snake from Australia. By G. A. Boulenger, F.R.S.}

Two years ago I described in these 'Annals' * a new Elapine snake discovered by Mr. W. Stalker near Alexandria, in the Northern Territory of the colony of South Australia, and which formed part of a small collection presented to the British Museum by Sir W. Ingram, Bart., and the Hon. John Forrest. That snake was named Lenisonia forresti. Mr. Stalker has continued collecting in the same district, and

* Ser, 7, vol. xviii. 1906, p. 440. 